\title{
Islamic Character Camp: Establishing Students Altruism Intelligence with Da'wa Communication
}

\author{
Yuliana Rakhmawati \\ Universitas Trunojoyo Madura, Indonesia \\ yuliana.r@trunojoyo.ac.id
}

\begin{abstract}
Altruism is one part of the Islamic teachings to bone people's care of others. Altruism da'wa in Islam as a form of teachings or principles should be taught to people from an early age or childhood. Altruistic character building can be started from the primary education environment. The purpose of this research was to describe the urgency and function of establishing the altruism character in the Ulil Albab Integrated Islamic Elementary School (SDIT) through the Islamic Character Camp. This research was conducted using a qualitative approach. Meanwhile, a theoretical sampling obtained the SDIT's principal and ICC's person in chief for interviews. The results showed that SDIT Ulil Albab beld da'wa communication by repackaging altruism messages and methods adjusted to the target, namely elementary school students. Strengthening the messages of altruism on an ongoing basis with alternative and contemporary media is necessary for future research.
\end{abstract}

Keywords: altruism, Islamic character camp, da'wa communication.

\begin{abstract}
Abstrak
Altruisme merupakan salah satu bagian dari ajaran Islam untuk mengasah kepedulian umat kepada sesama. Dakwab tentang altruisme dalam Islam sebagai bentuk pengajaran seyogyanya dilakukan pada umat sejak usia dini atau anak-anak. Pembangunan karakter altrustik dapat dimulai dari lingkungan pendidikan dasar. Tujuan riset ini adalab mendeskripsikan urgensi dan fungsi pembangunan karakter altruisme pada Sekolah Dasar Islam Terpadu (SDIT) Ulil Albab melalui kegiatan Islamic Charater Camp. Pendekatan kualitatif digunakan dengan sampling teoretis pada jajaran manajemen dan penyelenggara kegiatan. Hasil menunjukkan babwa komunikasi dakwah altrusime dilakukan dengan pengemasan pesan dan metode yang disesuaikan dengan target yaitu murid sekolah dasar. Melalui ICC nilai altruisme ditanamkan dengan aktivitas kelompok dan pembiasaan ibadab berjamaah. Penguatan pesan altruisme secara berkelanjutan diperlukan dengan media alternatif dan kontemporer.
\end{abstract}

Kata kunci: altruisme, islamic character camp, komunikasi dakwah.

Permalink/DOI: https://doi.org/10.18326/infs13.v14i1.25-48 


\section{Introduction}

Islamic belief gives an obligation on every Muslim to become rahmatan lil alamin. The spirit of rabmatan lil alamin that embrace in every Muslim could be pursuit by the generous sharing and caring behavior (Beik, 2009); (Miswaty, 2019). Since the sharing and caring behavior as a part of Islamic golden rules, it teaches that by being a generous person, many advantages can be obtained both as individuals and the benefit of others (Uyun, 2015). In general, from social scholars' perspectives, mention the sharing and caring behavior as altruism. Thus, as a religion, Islam has performed major concern in the quality of being kind and generous humankind. Islamic altruism presents as an unconditional belief or caring and giving practice all donations -in various forms- for the welfare of others (Amaroh, 2014). The idea of altruism as the basis of charity behavior is taught in Islam even from early childhood (Sa'adah \& Rahman, 2015). Therefore, altruism in Islam becomes part of the reflection of sufficient emotional intelligence (Yunico, Lukmawati, \& Botty, 2016).

Islam conceives the individual's right to private ownership but provides a reminder about other parties' rights involved. Hence, in this context, altruism becomes an obligatory idea for Muslims (Latief, 2013). Islam practices the value of altruism in two forms: obligatory (zakat), and voluntary (infaq, sadaqah, and waqaf). Zakat employs specific and binding provisions, but the voluntary model is done more freely (Alawiyah, 2009). In a wider context, this concept could enhance the initiation of a shared economic model (Maika, 2017).

Islam teaches the altruism insight from an early age and even from the womb during mother pregnancy. The given message by parents is essentially the first da'wa communication received by children (Saputra, 2014). Parents obligated to teach their children about appropriate morals learning, whereas education is a gateway to the teaching of science and knowledge (Alimuddin, 2014). At the level of formal education, enrichment about religious themes and practices also needs to be developed, especially at the level of primary education (Zuchdi, Prasetya, \& Masruri, 2009).

Primary education becomes a fundamental stage for giving 
value understanding (Utari, Degeng, \& Akbar, 2016); (Suyanto, 2012). The inculcation of religious values at the level of primary education conducted with a variety of learning models (Wiyono, 2012). Elementary school-age children in primary education experience a psychological phase to imitate the dominant significant others in the nearest environment (Setiawati, 2006); (Sit, 2015). Therefore, the cultivation of character education in primary school children becomes relevant and urgent to do. Hence, Islamic education should provide the ability to giving a contribution to these noble ideals. Islamic education, particularly the primary education institutions, instill positive ideas and values in their teaching environment (Rizqillah, Khamidun, \& Nurussa'adah, 2013). SDIT Ulil Albab, located in Kamal, Bangkalan, is one of the Islamic primary education institutions that commit to building the excellent youth, hold moral principle, and future independent generation.

Therefore, SDIT Ulil Albab performs strategies to harmonize the integrated Islamic school's network (JSIT) based curriculum with the national qualifications framework (kurikulum pendidikan nasional). This institution held primary education with a particular graduate competence standard (SKL) indicator. Sani \& Kadri (2016) pointed learning models should refer to the achievement of knowledge, attitudes, and skills competencies based on strengthening student participation and character education. SDIT Ulil Albab runs a vision of learning as an implementation of da'wa communication. Hence, there are normative and moral obligations applied in its learning process.

Islamic character camp (ICC) is the SDIT Ulil Albab's preferential program in delivering da'wa communication. This event held every semester, with all students are required two days to stay at school. Activities run-down consider the student competencies and the practice of religious values in daily life achievement. This program promotes the persuasive approach through reasoning and fun activities in da'wa communication.

Several different themes were taken in each of the program's implementation. The second ICC was held in 2019 to pursuit an altruism character building. According to the researcher, the altruism 
character establishment theme in the ICC SDIT Ulil Albab's is an interesting event as a form of da'wa communication innovation, as well as to identify obstacles in its implementation. The research findings hopefully were insightful as future scientific literature, particularly in da'wa communication themes, Islamic altruism, and primary Islamic educational nature.

\section{Literature Review}

Conceptual Insight of Altruism

Altruism is a French terminology that was first used as a concept by the positivism sociologist Auguste Comte in the book "Systeme de Politique Positive" (Scott \& Seglow, 2007, p. 1). According to Comte, altruism is an attitude of eliminating selfish desires and egocentrism and leading a life aimed at the welfare of others. The etymology of altruism is a combination of the Latin term "alter" with ui, which refers to other people. Later in the English version, it was mentioned as altruism and was introduced by George $\mathrm{H}$ Lewes -a Comte's follower.

Thomas Nagel, an American philosopher, called altruism as a willingness to act and do something for the benefit of others without ulterior motives (Ricard, 1976, p. 16). The altruism refers to a rational determination to contribute to the interests of others by not bringing reasons for personal gain. Another scholar, Stephen Post places altruism as a form of human affection for selflessness as a form of preference for putting others first (Ricard, 1976).

Villegas (2016) stated that basically, the act of altruism is an act of transaction. The process involved three participant parties: the giver, the liaison, and the recipient. The first part refers to an individual or entity that has more value in the form of money, goods, knowledge, intelligence, or physical strength that can be divide for others. The second part is a moral authority, a power that encourages the first party to give a portion of the value to third parties while third parties refer to "victims" or objects that need to get help from the first party.

Islam recognizes altruism as an act of sharing and caring by zakat, infaq, and sadaqah practicing. This value becomes an 
inseparable part of the development of the Muslim charity pattern. Uyun (2015) calls the practice of Altruism in Islam as a configuration of Islamic philanthropy. The practice of Islamic philanthropy itself has dynamically developed in philosophical perspectives, the essence of da'wa communication, and its contact with technology that cannot be avoided (Rakhmawati, 2019).

\section{Da'wa Communication: Messages, Media and Methods}

There are various concepts of da'wa from an etymological perspective (Suriani, 2017). In da'wa, there are built-in functions, including to educate the human soul, be patient and strive to fight, return to Allah's path, and present a gentle example. According to (Ilaihi, 2010), every Muslim should be an interpreter or communicator of the da'wa message both for himself and for others. As a da'wa communicator, there are several functions inherent in it in capacity and quality. There are at least six characters of the subject or da'wa communicator, such as readiness, sincerity, trustworthiness, calmness, friendliness, and simplicity (Suriani, 2017).

Da'wa communication employs several methods, including bil lisan (with words or speech), bil hal (with deeds), and bil qalam (with writing) (Nurdin, 2014). Recently, the dawa communication approach shifts from traditional linear patterns to more interactional (Maghfiroh, 2016). In contemporary dawa, the involvement of creativity in media selection and methods also contribute to the success of dawa communication conducted (Yanti, 2016).

The development of human dynamics as the subject and object of da'wa communication urge the media innovation and methods employed. Entering the digital era, the concept of da'wa and its accompanying components also transformed; one of them is the development of communication technology utilization (Basit, 2013). Islam sees da'wa communication functions to create transcendental relationships in religious rituals (babluminallab) and to understand horizontal relationships with others called habluninannas (Bakti \& Meidasari, 2014). Despite the various media and methods in da'wa communication, it bound with Islamic da'wa basic principles in AlQur'an that should be delivered by ahsanu qawla in the form of 
gentle words and kind deeds (Ariani, 2012).

\section{Research Methods}

This research aims to describe the altruism value establishment in Islamic character camp (ICC) SDIT Ulil Albab, Kamal-Bangkalan. The choice of SDIT Ulil Albab as the location of this study was due to several considerations. First, this educational institution became the first Islamic-based primary education initiator in the Kamal region, Bangkalan District. Second, SDIT Ulil Albab used a combination of a national curriculum framework and a consortium of integrated Islamic school networks as the learning method. Third, the managers and education personnel are young people who are enthusiastic and have motivation in the implementation of primary education based on Islamic values. This research used da'wa communication as the object of research. The research subject referred to informant character who has the competence and qualifications in answering questions about the research object. By using purposive sampling, this research found the principal of SDIT Ulil Albab and the person in chief of the steering committee of the ICC 2019/2020 as informants.

Data collection is done by interview, observation, and documentation. Triangulation, as a data validity checking technique is carried out using source and methods techniques. Source triangulation is conducted by taking a purposive number of informants relevant to the research objectives. The triangulation of methods was carried out eclectically from interviews and searching for documentation related to the research object. Data analysis was performed in four stages: data reduction, data display, data verification, and make logical inference.

This research conducted using a semi-structured interview method. Interview guides had been used to explore information from interviewees. The general information gather is about the implementation of the ICC and its effectiveness in learning about altruism. Some question points in the interview guide include the initiation of Islamic primary education institution establishment in Kamal, curriculum and management used in teaching, various programs conducted by SDIT Ulil Albab in achieving student learning competency units, the urgency of the ICC program, consideration of 
choosing altruism themes in the implementation of the ICC, and the effectiveness of the ICC program in achieving learning indicators.

Furthermore, this research takes primary education as a reference in describing the role of da'wa communication in instilling the values of religious teachings. Primary education in Islam is a stepping stone in the formation of rabmatan lil alamin. From the results of data collection by interviewing, observing, and using related documents, there are several categories of findings. Furthermore, the results analyzed and discussed from the perspective of the concept and the theory of da'wa communication. In addition, the use of previous research results from related journals is also helpful literature.

\section{Results And Discussion}

\section{Da'wa Communication At SDIT Ulil Albab}

SDIT Ulil Albab serves as primary Islamic educational since 2014 in Kamal sub-district, Bangkalan district. Until this research was conducted, SDIT Ulil Albab was the only SDIT in the Kamal subdistrict area. This school management is responsible for Insan Madani Foundation, Bangkalan. A principal coordinates SDIT management with several supporting divisions (curriculum, student affairs, public relations, and facilities). A person in charge plays as coordinator to supervises each student's competency (Al Qur'an and Tahfidz, library, extracurricular, and counseling guidance coordinator). Each class has one homeroom teacher and an associate teacher, whose inherent function is to supervise and assist students who are under their responsibility.

As an Islamic education provider, SDIT Ulil Albab not only referring to the national education curriculum but also incorporated with the consortium of integrated Islamic schools Network (JSIT) curriculum. Hence, in its implementation, integrated Islamic school combine general and religious education into a curriculum. Integrated Islamic schools also emphasize integration learning methods to optimize the cognitive, affective, and conative domains. Furthermore, SDIT also combines aqliyah and rubiyah as well as jasadiyah education. 
Islamic primary education gives basic environmental roles to persuade Islamic virtue. According to Fajarwati (2014), the inculcation of Islamic values among elementary students should consider with their characteristics. Therefore, the ability to identify learning themes and learning participants is a must. Primary education becomes an essential stage in shaping the character of students (Omeri, 2015). Planting characters in primary education can be done with various approaches such as the technique of songs (Rosmiati, 2014); multicultural values (Kartikawati et al., 2018); education integration (Kurniawan, 2013); with a cultural basis (Ghufron et.al, 2017); multimedia-based (Suyantiningsih et al., 2016); and integration of national character values (Ghufron, 2010).

Previous research by Mujib (2015) found that Islamic education has the responsibility to perform spiritual aspects of transformation and internalization. The process pursuit with some inherent spiritual messages such as the meaning of religious teachings, transcendence motivation in every activity, and the connectedness of future results. The formation of sensible, prudent humankind (ulil albab) has been conducting by touching all human dimensions to search the happiness and psychological well-being (Mujib, 2015).

SDIT Ulil Albab is aware of the consequences as a provider of Islamic education. Since this obligation reminds, the institution's vision idea is to become a primary education provider based on the Qur'an character, morality, and independence. SDIT Ulil Albab's curriculum includes an integrated character building for elementary school students. In its implementation, it combines the involvement and invites active participation among learning environments, schools, homes, and communities. Ulil Albab's student instills with practical learning, and it is associated with the Al-Qur'an and hadith.

SDIT Ulil Albab organizes education by actively providing access to stakeholders, including parents or student's guardians, to be involved in school development. The value of togetherness is realized by involving all entities in supporting the learning process. The school's principal mentions that this collaboration is done to foster a sense of ownership among the stakeholders of SDIT Ulil Albab. The concept is to provide synergy and reinforcement 
of input, ideas, or initiation in several school programs. There are several activities for parents, such as daily students worship monitoring at home, monthly parent and teacher meeting (POSG), and held parenting class every semester. Thus, the activities provide communication between school and parents. POSG serves as a channel for evaluating students' development reciprocally for both teachers and parents.

The learning process held in SDIT UA works with da'wa intention. Despite the contemporary da'wa form, SDIT UA employs a character-building learning process method. Since the da'wa object remains in elementary students, it is conducted with suitable message design and application. Therefore, SDIT Ulil Albab understands the shifting of the da'wa audience profile due to dynamic changes in demographic character as well as sociological and psychological dimensions. Da'wa communication initiated by this institution is carried out in synergy with curriculum learning. In each subject, the dimensions of knowledge (cognitive), attitudes (affective), and skills (psychomotor) present as students' competency achievement targets.

In the traditional perspective, da'wa is often identified with lectures or tabligh (Basit, 2013). Mowlana (1996) called dawa (tabligh) as a communication and ethics combination. However, in da'wa, there are different characters and patterns compared to other dimensions of communication, mainly in its motives and goals. In achieving the objectives of da'wa, communication plays an essential role as a catalyst (Bakti \& Meidasari, 2014). Communication will help identify the da'wa elements such as communicators, messages, media, communicants, and feedback. In its development, contemporary da'wa communication brings a pattern shifting of information transfer from the da'wa in more dynamically and openly.

SDIT Ulil Albab lead da'wa communication in three primary dimensions, such as da'wa messages substance, selection of da'wa media, and methods used in the practice of da'wa. Da'wa communication becomes an inseparable part of SDIT Ulil Albab learning and curriculum. Thus, the da'wa communication implementation is convergent with the learning process. The 
findings of this research on the da'wa communication conducted by SDIT Ulil Albab, Kamal can be seen in the following table:

Table 1. SDIT Ulil Albab's Da'wa Communication

\begin{tabular}{|c|c|c|}
\hline Dimension & Part & Practices \\
\hline \multirow{3}{*}{ Message } & Aqidah & $\begin{array}{l}\text { Thematic subjects with particular } \\
\text { indicators }\end{array}$ \\
\hline & Akblaq & $\begin{array}{l}\text { Thematic subjects and daily practices } \\
\text { in building relationships with fellow } \\
\text { school friends, with clerics (ustad/ } \\
\text { ustadzah), parents, and with the } \\
\text { surrounding environment }\end{array}$ \\
\hline & Syariab & $\begin{array}{l}\text { Thematic subjects to get an } \\
\text { understanding of the basic laws in } \\
\text { Islam. }\end{array}$ \\
\hline \multirow[b]{2}{*}{ Medium } & Oral & $\begin{array}{l}\text { Delivered directly in class with } \\
\text { speech. }\end{array}$ \\
\hline & $\begin{array}{l}\text { Mediated (written, } \\
\text { illustration, and } \\
\text { audio-visual) }\end{array}$ & $\begin{array}{l}\text { The media referred to learning } \\
\text { innovations such as using tools with } \\
\text { several simulated themes such as: } \\
\text { ablution practices, prayer practices, } \\
\text { charitable activities }\end{array}$ \\
\hline \multirow{3}{*}{ Method } & bil bikmah & $\begin{array}{l}\text { Conduct teaching with patience and } \\
\text { set an example to SDIT students. }\end{array}$ \\
\hline & $\begin{array}{l}\text { bil mau'idhah } \\
\text { hasanah }\end{array}$ & $\begin{array}{l}\text { Give advice and reprimand in a } \\
\text { good way to students in accordance } \\
\text { with the child's ability to receive the } \\
\text { message. }\end{array}$ \\
\hline & $\begin{array}{l}\text { bil mujajalah billati } \\
\text { biya absan }\end{array}$ & $\begin{array}{l}\text { In the simplest context is to } \\
\text { provide opportunities for students } \\
\text { to express their opinions about an } \\
\text { event can be done verbally or with } \\
\text { media messages, for example by } \\
\text { expressing pictures or writing. }\end{array}$ \\
\hline
\end{tabular}

Source : processed by researchers (2020)

The da'wa communication character has a particular message nature that contains to do positive things suggestions and prevent the harmfull one (Arifin, 2011). Islamic studies give attention to da'wa in ideal, normative, and textual concepts regarding the Qur'an and 
Sunnah. However, from a sociological perspective, da'wa is seen as part of social phenomena where the theoretical point of view is rational, empirical, actual, and contextual (Arifin, 2011).

The management of SDIT Ulil Albab uses a diverse perspective in conducting da'wa communication with students. The message of da'wa still refers to the references of the Qur'an and Sunnah. Nevertheless, in the media and methods, there is an adjustment for some purposes. SDIT Ulil Albab made this adjustment to accompanying the profile of elementary school-age communicants. According to the management of SDIT Ulil Albab, the message learned by students in school should be repeated at home. This method is done in encouraging parents to strengthen students understanding in their daily habituation. Thus, for this purpose, the school provides a contact book for evaluating student performance at home in the worship activities and moral habitual.

\section{Islamic Character Camp: Building Altruism Spirit}

The teachings about Islamic altruism or the value of generosity are conveyed in several verses of the Qur'an: Al Bayinah (5), Al Mukminun (1-4), An-Nur (33). In all Muslim's wealth, there are rights from other parties that must be fulfilled. Islamic altruism was developed based on the "metaphor" of zakat, which emphasizes the point of balance. Triyuwono (2007), as quoted in (Mulawarman, 2007) said zakat-based metaphorical balance implicitly contains egoistic-altruistic, material-spiritual, and individual-collective values.

In the da'wa communication context, an altruism message is an important theme that needs to be instilled from an early age. Da'wa activities as a communication process in the distribution of Islamic teachings have the power to increase knowledge, influence attitudes, and behavior change the da'wa target (Mahfud \& Kertamukti, 2016). The subjects of da'wa in learning at SDIT are teachers who actively provide stimulus to students so that they can absorb the given themes. The da'wa objects referred to students who will be evaluated periodically related to their studied themes competencies.

The choice of altruism as a point of internalization at SDIT Ulil Albab is inseparable from the mission of organizing education that 
generates independent, durable, and brotherhood generations. As stated by the Principal of SDIT Ulil Albab, that character education is the main point in the administration of education at the institution he leads. It is hoped that this vision can be realized in curricula and various measurable and sustainable strategic work programs.

The ICC is one form of responsibility of Islamic educational institutions in achieving the ultimate goal of education to fit form human nature and humanity's students. Farida (2015) wrote that during the Islamic golden era, education had played its role as a catalyst for strengthening students from all aspects and elements of self-development. The triumph of Islamic education has become a motivation for the SDIT Ulil Albab's teachers (ustad and ustadzah) to delivering optimal learning. The activity during the ICC was scheduled with several activities such as opening ceremony, division of the team, making team yells, prayer in congregation, dhikr in the evening, group assignments, and closing sessions. Each activity has a purpose and contributes to the learning of particular students' competencies. Those competencies refer to Islamic's cognitive (knowledge) competencies, affective (attitudes), and behaviors.

Since it had been established in 2014, SDIT Ulil Albab has held Islamic Character Camp for the second time. The students of 2nd, 3rd, 4th, and 5th-grade become the participants. ICC pursues the students to understand the concepts of ethical values in Islam. According to the 2019 ICC person in chief, this activity will be held regularly to build students' social awareness character. In this annual event, it declares a different theme every year. In 2018 as the first event held, the theme got to be "Qur' ani, morally, and independent" students. Furthermore, the second event in 2019 took "civilized, agile, and caring" as the theme. The ICC was carried out with the concept of camp, where for two days and night, the students were given a briefing and fostering the manners, dexterity, and care of the student's character.

The ICC committee approaches elementary students with suitable message design to strengthening altruism as life skills internalization. The committee also provides the practice of altruism values as a religious habit. The integration method made altruism 
values becomes an essential part of formal education as a form of institutional responsibility to stakeholders. Schools should ideally be one of the cornerstones for the transfer of noble values both in the context of personal and public interests (Ichsan, 2019).

According to SDIT Ulil Albab Principal, Islamic altruism will be easier to understand when it is carried out with a suitable learning method. Its mission is to be able to provide understanding to children of the value of altruism as a representation of maintaining brotherhood (ukhuwab). Giving and sharing to Muslims fellow, other people, and the environment, in general, is a reflection of the brotherhood of the ummah (ukhuwah). In learning Islamic altruism practices, the school habituates students' in daily life activities, such as helping one another when friends need help, collecting class cash for joint activities, and doing mutual assistance work every weekend.

In general, ICC activities are divided into physical and nonphysical (spiritual) activities. Physical activity is implemented with morning exercises to maintain student's health, then proceed with natural tadabur with a leisurely walk around the school environment. The spiritual activities were accomplished by praying in congregation, memorizing the Quran (murojaab), and doing morning-evening pray. This habit of worship ritual activities is expected to strengthen students' perseverance in worship.

Figure 1. Morning exercise as a physical activity of students at the ICC

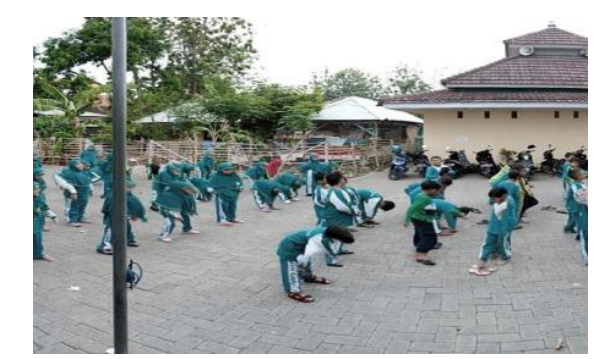

(source: instagram@sditulilalbab_kamal) 

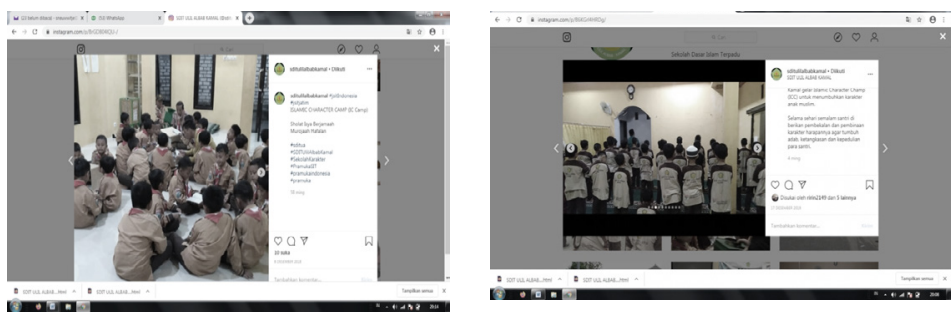

Figure 2. Student worship activities during the ICC (source : instagram@sditulilalbab_kamal)

Islamic education is capable of presenting an atmospheric altruism environment closer to the students. Rahmawati (2019) mentioned that altruism is the basic foundation of prosocial behavior, as in the teachings of Islam, by giving to others without expects rewards reciprocally. Furthermore, some researchers conveyed that formal education was able to contribute to the internalization of the altruism messages through the application of an Islamic school atmosphere. However, the implementation is adjusted with the level of readiness with the infrastructure and superstructure of related educational institutions.
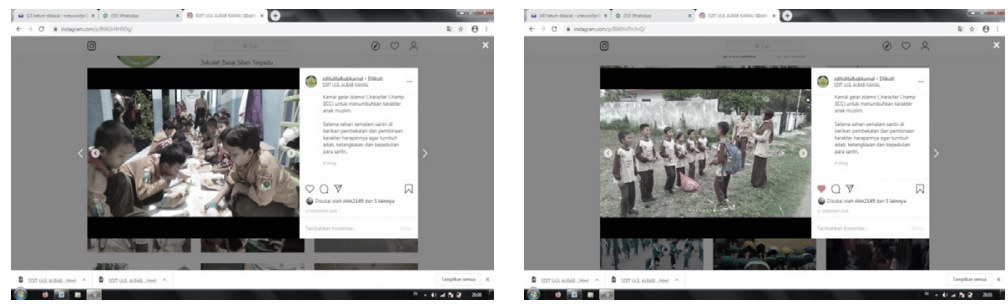

Figure 3. Activities to instill the value of altruism (source: instagram@sditulilalbab_kamal)

The use of game and fun learning concepts as ethnoedutainment becomes habituation that significantly influences the learning process (Ardianti, 2019). The form of habituation made the concept of da'wa education get closer to the elementary students. This method uses the psychological development of elementary school-age children an approach. Although altruism is often referred to as human social life simple concept, for some children, giving understanding does not always take place easily. 
ICC SDIT Ulil Albab provides altruism learning in several forms of activities. In the initial stages, the teachers deliver a speech about Islamic altruism virtues to the students. The next step is to practice various activities, such as eating together and teamwork projects. Students are divided into groups with some task descriptions to accomplish. The division of groups is done by integrating students from lower classes (the second or third grade) with upper classes students (the fourth and fifth grades). This diverse group format is to pursuit students' understanding of altruism values. These activities form students for cooperation, respecting the opinions of others, learning to compromise, expressing opinions, and sharing assignments according to an agreement.

Previous research from Suyadi (2018) showed the character building in primary age lead for some benefits: to avoid personal problems in adulthood, including averting corrupt behavior. Furthermore, Siswanta ( 2017) conveys that human personal community ability is predominantly formed by emotional intelligence (80\%), while intellectual intelligence only contributes as much as $20 \%$. The environment is one of the determinants in the formation of children's character, one of which is the educational environment. Education contributes to the conformation of plenary humans with balanced and relevant cognitive, affective, and psychomotor aspects (Rasimin, 2017). The formation of character in children's education emphasizes more on life skills aspects such as divine orientation, independence and responsibility, honesty, generosity, self-confidence, creativity, hard work, leadership, humility, and tolerance.

The ICC work program implementation has considering a particular theme. The ICC program's effectiveness relay in the form of student competency achievement. In the 2019 ICC held with altruism theme. Student competencies were divided into three areas: cognitive, affective, and psychomotor. During the implementation of the ICC, students get an evaluation of altruism points competence achievement. The results of student evaluations become an indicator of the ICC implementation effectiveness. According to the school principal, the ICC implementation is an effective way to conduct da'wa communication at SDIT Ulil Albad. The results of data analysis 
and discussion of the ICC program effectiveness can be seen in the following table:

Table. 2 The ICC Program Effectiveness Achievement

\begin{tabular}{|c|c|c|}
\hline Indicators & Activities & Students Achievement \\
\hline \multirow[t]{3}{*}{ Cognitive } & $\begin{array}{l}\text { Formality cere- } \\
\text { mony }\end{array}$ & $\begin{array}{l}\text { Students become more dis- } \\
\text { ciplined by using uniforms } \\
\text { according to the provisions. } \\
\text { Therefore, students required } \\
\text { to follow the procedure by } \\
\text { making a neat line during cer- } \\
\text { emonial. Students understand } \\
\text { the responsibilities as a cere- } \\
\text { monial officer, as well as the } \\
\text { obligations as participants of } \\
\text { the ceremony. }\end{array}$ \\
\hline & Jama'ah prayer & $\begin{array}{l}\text { These activities not only per- } \\
\text { form students to have the } \\
\text { ability to perform compulsory } \\
\text { worship but also brotherhood } \\
\text { spirit. Jama'ah prayer gives to- } \\
\text { getherness, strata, and equali- } \\
\text { ty position message. Students } \\
\text { appreciate wholeness and the } \\
\text { value of submission to a leader } \\
\text { and control of people's lives. }\end{array}$ \\
\hline & Group division & $\begin{array}{l}\text { Students become individuals } \\
\text { who can work in a team. Stu- } \\
\text { dents understand the different } \\
\text { characters and traits of their } \\
\text { peers and learn to respect each } \\
\text { other. Students also learn to } \\
\text { make task descriptions among } \\
\text { group members. }\end{array}$ \\
\hline
\end{tabular}




\begin{tabular}{|c|c|c|}
\hline Indicators & Activities & Students Achievement \\
\hline & $\begin{array}{l}\text { Doing morning } \\
\text { and night dhikr }\end{array}$ & $\begin{array}{l}\text { To create a good ubudiyah } \\
\text { tradition, students are not only } \\
\text { directed so to attend the con- } \\
\text { gregational prayer but also do } \\
\text { the morning and night dhikr. } \\
\text { These activities are maintained } \\
\text { and disciplined by the SDIT } \\
\text { Ulil Albab's teachers to maxi- } \\
\text { mize the students' competen- } \\
\text { cy achievement. This activity } \\
\text { trains students' patience and } \\
\text { sincerity in prayer. }\end{array}$ \\
\hline Affective & $\begin{array}{l}\text { Communal } \\
\text { meals }\end{array}$ & $\begin{array}{l}\text { This dining activity taught stu- } \\
\text { dents to share. From these } \\
\text { activities, students can under- } \\
\text { stand the rights and obliga- } \\
\text { tions of life together. Students } \\
\text { are able to share with oth- } \\
\text { er students when it comes to } \\
\text { food or when cleaning used } \\
\text { food utensils. }\end{array}$ \\
\hline \multirow[t]{2}{*}{ Psychomotor } & $\begin{array}{l}\text { Tilawah dan } \\
\text { Muroja'ah after } \\
\text { morning and } \\
\text { night prayers }\end{array}$ & $\begin{array}{l}\text { Worship activities are carried } \\
\text { out by performing the ritual of } \\
\text { reading the Qur'an. The hab- } \\
\text { it is to practice time manage- } \\
\text { ment for students. From this } \\
\text { activity, the students were able } \\
\text { to increase their ability to read } \\
\text { the Qur'an better. }\end{array}$ \\
\hline & Group mission & $\begin{array}{l}\text { The determined group has a } \\
\text { mission to run. Each group } \\
\text { asks to work together to com- } \\
\text { plete the mission in several } \\
\text { posts. The activity trains stu- } \\
\text { dents' concern to work togeth- } \\
\text { er in completing assignments. } \\
\text { Every student in the group } \\
\text { has a role and contribution to } \\
\text { achieving group goals. }\end{array}$ \\
\hline
\end{tabular}




\begin{tabular}{|c|c|c|}
\hline Indicators & Activities & Students Achievement \\
\hline & Sport & $\begin{array}{l}\text { A healthy physique is need- } \\
\text { ed to support other activities. } \\
\text { This activity encourages stu- } \\
\text { dents always to maintain phys- } \\
\text { ical health. At the same time, it } \\
\text { teaches integrity and cares for } \\
\text { a healthy lifestyle. }\end{array}$ \\
\hline
\end{tabular}

Source: processed by researchers (2020)

SDIT Ulil Albab character building with the ICC program refers to da'wa communication through activities to convey religious teachings and moral values. Positive activities in shaping the character of students with the habit of adjusting to the understanding of the age of students with the accompanying practice activities. The implementation of the ICC is in line with the objectives of character education as contained in Law No. 20 of 2003 concerning the National Education System to print human beings who are virtuous and devoted to God Almighty (Ristekdikti, 2016). ICC has also referred to the 2013 Curriculum with the target of achievement to prepare Indonesian people who are independent, devoted, able to communicate with the community, civilized, productive, creative, innovative, have social care, national and state awareness.

\section{Conclusion}

Generally, da'wa communication consists of three critical components: messages, media, and methods. In communication scholars' perspectives, da'wa communication contains the tradition of rhetoric. It determinates to three competencies: ethos, pathos, and logos. The dynamic development of the da'wa target considers this approach to met tight expectations. Recently, in practical implementation, da'wa communication requires more creativity and ideas that are tailored to the da'wa profile target.

The implementation of ICC by SDIT Ulil Albab is part of the da'wa communication innovation performed by Islamic educational institutions. The initiation of the SDIT Ulil Albab da'wa innovation is not a concern in the da'wa message substance nor the da'wa 
method, but instead on the media used. SDIT Ulil Albab uses ICC as media to bring altruism learning in a novelty approach. The series of ICC activities packaging is delivered to match the target competencies achievement. The research analysis obtained that the ICC program effective in encouraging student's cognitive, affective, and psychomotor competencies. The school evaluation of the ICC program concluded that this program could foster students to reach sufficient capacity of altruism knowledge, attitudes, and practicing altruistic behavior.

Initiation for further research could employ a higher level of education with a more diverse target profile. The positivistic paradigm could run for mapping the Islamic altruism potential in the broader character population. With the various Islamic altruism findings, the development of perspective and the practical charity will develop in the future. The variety of findings can be a reference for people to become an intelligent and insightful philanthropist. 


\section{References}

Alawiyah, T. (2009). Korelasi Perbuatan Beramal Dengan Besarnya Nominal Umat Islam Indonesia . Zakat and Empowering Jurnal Pemikiran dan Gagasan - Vol II.

Alimuddin, N. (2014). Komunikasi Dakwah dalam Bimbingan Sosial Menumbuhkan Kemampuan Adaptasi Ma'du. Al Misbah Vol 10 No 2, 241-256.

Amaroh, S. (2014). Prinsip Keadilan Sosial Dan Altruisme Dalam Penerapan Sistem Perbankan Syariah. Economica Volume V/Edisi 2/Oktober, 87-106.

Ardianti, S. D. (2019). Respon Siswa dan Guru Terhadap Modul Ethno-Edutainment di sekolah IslamTerpadu. dukasia: Jurnal Penelitian Pendidikan Islam Vol. 14, No. 1, Februari, $1-24$.

Ariani, A. (2012). Etika Komunikasi Dakwah menurut Al-Quran . Alhadharah Jurnal Ilmu Dakwah Vol. 11 No. 21, Januari - Juni, 7-16.

Arifin, A. (2011). Dakwah Kontemporer Sebuah Studi Komunikasi. Yogyakarta: Graha Ilmu.

Bakti, A. F., \& Meidasari, V. E. (2014). Trendsetter Komunikasi di Era Digital: Tantangan dan Peluang Pendidikan Komunikasi dan Penyiaran Islam. Jurnal Komunikasi Islam Volume 04, Nomor 01, Juni, 20-44.

Basit, A. (2013). Dakwah Cerdas di Era Modern. Jurnal Komunikasi Islam, 3(1), https://doi.org/10.15642/jki.2013.3.1.\%p.

Beik, I. S. (2009). Analisis Peran Zakat dalam Mengurangi Kemiskinan : Studi Kasus Dompet Dhuafa Republika . Zakat \& Empowering Jurnal Pemikiran dan Gagasan - Vol II .

Fajarwati, I. (2014). Konsep Montessori Tentang Pendidikan Anak Usia Dini Dalam Perspektif Pendidikan Islam. Pendidikan Agama Islam, Vol. XI, No. 1, Juni, 37-52.

Farida, Y. E. (2015). Humanisme Dalam Pendidikan Islam. Jurnal Tarbawi Vol. 12. No. 1. Januari -Juni, 105-120. 
Ghufron, A. (2010). Integrasi Nilai-Nilai Karakter Bangsa Pada Kegiatan Pembelajaran. Cakrawala Pendidikan Mei Edisi Khusus Dies Natalis UNY, 13-24.

Ghufron, A., Budiningsih, C. A., \& Hidayati. (2017). Pengembangan Pembelajaran Berbasis Nilai-Nilai Budaya Yogyakarta Di Sekolah Dasar. Cakrawala Pendidikan, Juni No. 2, 310319.

Ichsan. (2019). Pendidikan Nilai Kejujuran Berbasis Kelas di Madrasah Ibtidaiyah Negeri 1 Bantul Yogyakarta. Edukasia: Jurnal Penelitian Pendidikan Islam Vol. 14, No. 1, Februari, 49-70.

Ilaihi, W. (2010). Komunikasi Dakwah. Bandung: Remaja Rosdakarya.

Kartikawati, D., Radjagukguk, D. L., \& Sriwartini, Y. (2018). Penanaman Nilai-Nilai Multikultural Melalui Komunikasi Pendidikan Di Sekolah Dasar Inklusi Di Yogyakarta Dan Surakarta. Widya Komunika Vol 8 No. 1 April, 59-75.

Kurniawan, M. I. (2013). Integrasi Pendidikan Karakter Ke Dalam Pembelajaran Kewarganegaraan Di Sekolah Dasar . Jurnal Pemikiran dan Pengembangan SD, Jilid 1, Nomor 1, April , 37- 45.

Latief, H. (2013). Filantropi Dan Pendidikan Islam Di Indonesia. Jurnal Pendidikan Islam Vol. XXVIII No. 1, 123-139.

Maghfiroh, E. (2016). Komunikasi Dakwah; Dakwah Interaktif Melalui Media Komunikasi. Dakwatuna: Jurnal Dakwab dan Komunikasi Islam Volume 2, Nomor 1, Pebruari, 34-48.

Mahfud, M., \& Kertamukti, R. (2016). Desain Komunikasi Dakwah Visual Animasi 2d Untuk Anak (Studi Deskriptif Kualitatif di SDN Monggang Pendowoharjo Sewon Bantul). ProfetikJurnal Komunikasi Vol.09/NO.02/Oktober, 45-64.

Maika, M. R. (2017). Model Ekonomi Berbagi“Mobile-Seco"(Platform Multi-Sided Markets) Sebagai Ekosistem Sosio-Ekonomi Islami . Isthisoduna Jurnal Ekonomi dan Bisnis Islam, 47-55 
Miswaty. (2019). Perilaku Berbagi Ilmu Menurut Pandangan Islam Dan Manfaatnya Dalam Profesi Akuntansi . Jurnal Ekonomi dan Manajemen (JEM) Vol 13 No 1, 29-38 .

Mowlana, H. (1996). Gloal Communication in Transition the End of Diversity? London: Sage Publication.

Mujib, A. (2015). Implementasi Psikospiritual Dalam Pendidikan Islam . MADANIA Vol. 19, No. 2, Desember, 195-210.

Mulawarman, A. D. (2007). Menggagas Neraca Syari'ah Berbasis Maal: Kontekstualisasi "Kekayaan Altruistik Islami. Jurnal Akuntansi dan Keuangan Indonesia Vol.4, No. 2 Desember, 169-192.

Nurdin, A. (2014). Akar Komunikasi Dalam Al-Qur'an (Studi Tematik Dimensi Komunikasi Dalam Al-Qur'an). Jurnal Kajian Komunikasi, Volume 2, 1, Juni, 12-26.

Omeri, O. (2015). Pentingnya Pendidikan Karakter Dalam Dunia Pendidikan. Manajer Pendidikan, Volume 9, Nomor 3, Juli , 464-468.

Rahmawati, S. (2019). Peran Iklim Sekolah Islami TerhadapAltruisme pada SMAIT Nurul Fikri Depok Jawa Barat. Edukasia: Jurnal Penelitian Pendidikan Islam Vol. 14, No. 1, Februari, 71-96.

Rakhmawati, Y. (2019). Studi Media Filantropi Online: Pergeseran AltruismeTradisional-Karitas menuju Filantropi Integratif. Komunika Vol 13 No 2.

Rasimin. (2017). Implementasi Model Pembelajaran Multikultural Untuk Meningkatkan Kompetensi Mahasiswa (Studi Pada Mahasiswa PGMI di IAIN Salatiga). Inferensi: Jurnal Penelitian Sosial Keagamaan Vol. 11, No.1, Juni, 141-162.

Ricard, M. (1976). Altruism: The Power of Compassion to Change Yourself and The World. New York: Little Brown Company.

Ristekdikti. (2016). kelembagaan.ristekdikti.go.id. Dipetik January 26, 2020, dari https://kelembagaan.ristekdikti.go.id/wpcontent/uploads/2016/08/UU_no_20_th_2003.pdf 
Rizqillah, A. H., Khamidun, \& Nurussa'adah. (2013). Metode Bercerita Sebagai Model Penanaman Pendidikan Agama Islam Untuk Anak Usia Prasekolah Pada Area Agama Taman Kanak- Kanak Di Desa Bogares Kidul Kecamatan Pangkah Kabupaten Tegal. BELIA 2 (1), 17-22.

Rosmiati, A. (2014). Teknik Stimulasi dalam Pendidikan Karakter Anak Usia Dini Melalui Lirik Lagu Dolanan. Resital Vol 15 no.1 Juni, 71-82.

Sa'adah, F. M., \& Rahman, I. K. (2015). Konsep Bimbingan Dan Konseling Cognitive Behavior Therapy (Cbt) Dengan Pendekatan Islam Untuk Meningkatkan Sikap Altruisme Siswa. Jurnal Hisbah, Vol. 12, No. 2 Desember, 49-59.

Sani, R. A., \& Kadri, M. (2016). Pendidikan Karakter: Mengembangkan Karakter Anak Yang Islami . Jakarta : Bumi Aksara.

Saputra, M. A. (2014). Internalization of Religious Values to Early Children at Palopo City. Jurnal "Al-Qalam" Volume 20 Nomor 2 , 197-210.

Scott, N., \& Seglow, J. (2007). Altruism . Berkshire : Open University Press .

Setiawati, F. A. (2006). Pendidikan Moral Dan Nilai-Nilai Agama Pada Anak Usia Dini: Bukan Sekedar Rutinitas. Paradigma, No. O2 Th. I, Juli, 41-48.

Siswanta, J. (2017). Pengembangan Karakter Kepribadian Anak Usia Dini (Studi Pada PAUD Islam Terpadu Di Kabupaten Magelang Tahun 2015). Inferensi: Jurnal Penelitian Sosial Keagamaan Vol. 11, No.1, Juni, 97-118.

Sit, M. (2015). Psikologi Perkembangan Anak Usia Dini . Medan: Perdana Publishing .

Suriani, J. (2017). Komunikasi Dakwah Di Era Cyber. Jurnal An-Nida Jurnal Pemikiran Islam Vol 41 No 2 Desember, 252-265.

Suyadi. (2018). Integration of Anti-Corruption Education (PAK) In Islamic Religious Education (PAI) With Neuroscience Ap- 
proach (Multi-Case Study in Brain Friendly PAUD: I Sleman Kindergarten Yogyakarta) . Inferensi: Jurnal Kajian Sosial Keagamaan Vol. 12, No.2, Desember, 307-330.

Suyantiningsih, Munawaroh, I., \& Rahmadona, S. (2016). Pengembangan Multimedia Pembelajaran Berbasis Scientific Approach Terintegrasi Nilai Karakter. Jurnal Kependidikan, Volume 46 Nomor $1 \mathrm{Mei}, 1-13$.

Suyanto, S. (2012). Pendidikan Karakter untuk Anak Usia Dini. Jurnal Pendidikan Anak, Volume 1, Edisi 1 Juni, 1-10.

Utari, U., Degeng, I. N., \& Akbar, S. (2016). Pembelajaran Tematik Berbasis Kearifan Lokal Di Sekolah Dasar Dalam Menghadapi Masyarakat Ekonomi Asean (MEA). Jurnal Teori dan Praksis Pembelajaran IPS Vol.1 No.1 April, 39-44.

Uyun, Q. (2015). Zakat, Infaq, Shadaqah, Dan Wakaf Sebagai Konfigurasi Filantropi Islam . Islamuna Volume 2 Nomor 2 Desember, 218-234.

Villegas, R. (2016). The History of Altruism. USA: Robert Villegas.

Wiyono, H. (2012). Pendidikan Karakter Dalam Bingkai Pembelajaran Di Sekolah. Jurnal Ilmiah CIVIS, Volume II, No 2, Juli.

Yanti, F. (2016). Komunikasi Dakwah dalam Kesenian Nasyid . Al Misbah Volume 12 Nomor 2 Juli-Desember, 211-231.

Yunico, A., Lukmawati, \& Botty, M. (2016). Hubungan Antara Kecerdasan Emosi Dengan Perilaku Altruistik Pada Mahasiswa Fakultas Ekonomi Dan Bisnis Islam Jurusan DIII Perbankan Syariah Angkatan 2013 Uin Raden Fatah Palembang . PsikisJurnal Psikologi Islami Vol 2 No 2, 181-194.

Zuchdi, D., Prasetya, Z. K., \& Masruri, M. S. (2009). Pengembangan Model Pendidikan Karakter Terintegrasi Dalam Pembelajaran Bidang Studi Di Sekolah Dasar. Cakrawala Pendidikan, Mei 2010, Th. XXIX, Edisi Khusus Dies Natalis UNY, $1-12$. 